\title{
STUDY ON THE PHYSICAL AND MECHANICAL PROPERTIES OF ANCIENT CLAY BRICK SAMPLES OF KATHMANDU VALLEY, NEPAL
}

\author{
Jagadeesh Bhattarai* \\ Dol Bahadur Ghale \\ Yagya Prasad Chapagain \\ Narendra Bahadur Bohara \\ Nijan Duwal
}

\begin{abstract}
Physical and mechanical properties of seven ancient clay brick samples of Kathmandu valley consisting of quartz, feldspars, spinel, margarite, muscovite type of mica mineral and hematite were studied using ASTM standards. All the brick samples used in this study have the water absorption, apparent porosity and bulk density in the range of 10-28 percent, $17-33$ percent and $1.2-1.8 \mathrm{~g} / \mathrm{cm}^{3}$, respectively, while the compressive strength of all the brick samples is found to be in the range of 5-23 MPa. The bulk density of the tile samples is found to be increased with decreasing the water absorption and apparent porosity. The compressive strength of all the clay brick samples can be correlated with their physical properties. Consequently, durability of the ancient bricks is directly influenced by their physical properties of water absorption, apparent porosity and bulk density.
\end{abstract}

Keywords: Archaeological brick, water absorptivity, apparent porosity, density, compressive strength, ASTM standards, fluxing oxides, archaeologically important

\section{INTRODUCTION AND OBJECTIVE}

The clay brick is homogeneous, harder and stronger due to the ceramic bond from the sintering phase of the silica and alumina clay constituents and it was one of the fundamental structural building materials in the Mesopotamian, Egyptian and Roman periods (Fernandes et al. 2010).

\footnotetext{
* Dr. Bhattarai is Professor of Chimestry, Central Department of Chemistry, Kirtipur, TU. Mr. Ghale is associated with Central Department of Chemistry, Kirtipur, TU. Mr. Chapagain is associated with Department of Chemistry, TriChandra Campus, Kathmandu, TU. Mr. Bohara is associated with Department of Chemistry. Mr. Duwal is associated with Department of Chemistry, St. Xavier College, Kathmandu.
} 
It is generally considered that the properties of such archaeological building materials of clay brick are essentially depended on the quality of the raw materials used for making it together with the manufacturing process technology. The ancient brick manufacturing techniques was depended on the supervisors and it was considered as the hereditary gifted knowledge passed on to generations from their forefathers (Hasan 1999). This is the main reason that the knowledge about the ancient clay brick materials and their application techniques which were so successfully used in the past has now disappeared without any documentation in our part of the world, because the properties of such types of clay bricks depend on their mineralogical compositions, manufacturing process and firing temperature (Bordia \& Camacho-Montes 2012).

The fired clay bricks are extremely durable and hence, there have been numerous archaeological structural buildings standing for centuries as a testimony of the survival of the clay-based fired bricks. The main factor to manufacture these bricks is the clay raw material types used and the firing temperature during their production, because both of these affect the quality and durability of bricks (Mostaghelchi et al. 2013; Rasmussen et al. 2012; Dunham et al. 2001; Dondi et al. 1999). A large number of studies have been reported about the ancient brick structures and materials to foster their cultural and economic importance in different parts of the world (Šarić et al. 2018; Amadori et al. 2017; Shu et al. 2017; Bartz \& Chorowska 2016; Oguz et al. 2014; Fernandes \& Lourenço 2007; Cardiano et al. 2004; Elert et al. 2003; López-Arce et al. 2003; Paama et al. 2000).

It is said that the durability (i. e., mechanical strength) of the clay bricks depends mainly on their mineralogical composition and physicosintering properties (Bordia \& Camacho-Montes 2012). The mineralogical and physical properties and mechanical strength of the fired clay bricks are generally interrelated to each others. It is reported that the firing temperature is one of the key factor to modulate the physical, sintering and mechanical properties of different types of brick samples (Ajala et al. 2017a, 2017b; Velraj et al. 2009; Karaman et al. 2006), but not the firing rate on kaolinite based ceramics (Njoya et al. 2017). Different physico-sintering properties (i. e., water absorption capacity, apparent porosity, apparent density, bulk density and so on) of clay bricks and their mechanical properties were investigated at different firing temperatures and the brick sample fired at $1100{ }^{\circ} \mathrm{C}$ showed the best mechanical properties (Martin-Marquez et al. 2010; Ghorbel et al. 2008; Yongue-Fouateu et al. 2016; Johari et al. 2010). 
In general, water absorption capacity, apparent porosity, bulk density are considered to be most important physico-sintering properties of all types bricks while the compressive strength is one of the important mechanical properties. All these physico-sintering and mechanical properties are reported to be inter-related to each other's and they affect the durability of all types of bricks even the archaeological clay brick samples.

The preservation of such archaeologically important ancient clay bricks has given rise to a considerable interest recently by archaeologists, architects, engineers and scientists, because the archaeological buildings needs to be restored with substitution of bricks when they damage. A good characterization of such archaeological clay brick specimens gives us a possibility to predict advance the chemico-mineralogical phases, physicosintering and mechanical behavior of the new formed building system. To learn about the historical understanding is not just to analyze and preserve such archaeological objects but also to investigate and understand the knowledge and skills used to produce and use them (Vandiver 2001).

The durability assessment of different types of clay bricks is mainly based on their technical physico-sintering and mechanical properties. However, such technical properties of the archaeological clay brick samples of Kathmandu valley are not reported in scientific communities, although mineralogy of the archaeological bricks (Ghale et al. 2018), fired clay bricks at different temperatures (Bohara et al. 2018) and ceramic tiles (Buthathoki et al. 2018a, 2018b) were recently reported by some of the present researchers in Nepal. It was reported that the mineralogical phases existed in the archaeological clay brick samples collected from Kathmandu valley were identified as quartz, feldspars, spinel, muscovite type of mica mineral and hematite, and such clay bricks were considered to be fired at 900-1000 ${ }^{\circ} \mathrm{C}$ for their production (Ghale et al. 2018). Considering these facts, the present research work was focused to carry impact assessments on three different physico-sintering properties of water absorption capacity, apparent porosity, bulk density and one mechanical property of the compressive strength of nine archaeologically important ancient clay brick samples using ASTM Standards (ASTM C20-00 2015; ASTM C1424152015 ) to know relation between the physico-sintering and mechanical properties of the ancient clay bricks. 


\section{METHODOLOGY}

The archaeologically important seven ancient brick samples were collected from the relics of Kathmandu Tower-Dharahara, Basantapur Durbar square, Balgopaleshwor Temple- Ranipokhari, Clock Tower building- Ghantaghar, Tripureshwor (Department of Consular Services), and Baghbhairav Temple and Pangaa of Kirtipur in this research work those were distracted by the great earthquake- April 2015, with the permission of concerned authorities. The detail descriptions of these eight clay brick sample specimens are summarized in Table 1 and the photographs of all these clay brick samples are shown in Fig. 1 (Ghale 2018).

Fig. 1: Photographs of ancient clay brick samples of Kathmandu valley
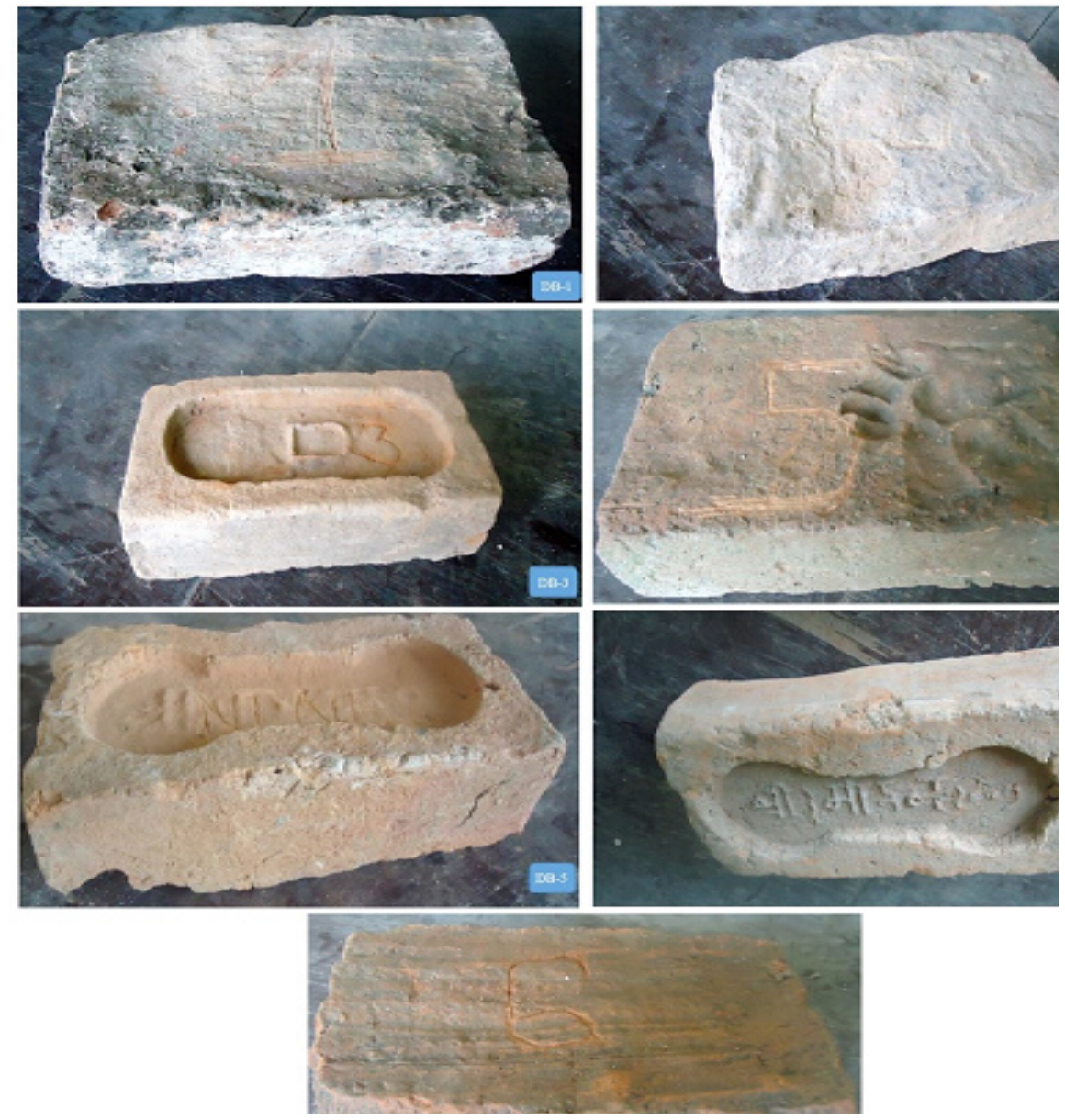

Source: Ghale 2018. 
Table 1: Description of the archaeologically important clay brick samples used in this study 2018.

\begin{tabular}{|l|l|l|}
\hline Place of Collection & Sample Code & Type \\
\hline Dharahara (Kathmandu Tower) & DB-1 & Ancient Brick \\
\hline Basantapur Durbar Square & DB-2 & Ancient Brick \\
\hline Ghantaghar (Clock Tower) & DB-3 & Ancient Brick \\
\hline Balgopaleshwor Temple ( Ranipokhari) & DB-4 & Ancient Brick \\
\hline Baghbhairav Temple-Kirtipur & DB-5 & Ancient Brick \\
\hline Tripureshwor-Dept. Consular Services & DB-6 & Ancient Brick \\
\hline Paanga-Kirtipur & DB-7 & Ancient Brick \\
\hline
\end{tabular}

It is meaningful to mention here that the mineralogical phase of these seven ancient clay brick samples was reported to be consisted mainly of quartz, feldspars, spinel, margarite, hematite and muscovite type of mica minerals from previous works (Ghale et al. 2018). In this study, the physical properties of water absorption capacity, apparent porosity and bulk density of the analyzed clay brick samples were estimated using following equations (1), (2) and (3) (ASTM C20-00 2015), respectively, were D is the weight of brick sample in dry condition $(\mathrm{g}), \mathrm{S}$ is the weight of brick sample in saturated condition $(\mathrm{g})$ and $\mathrm{V}$ is volume of outer sides $\left(\mathrm{cm}^{3}\right)$ of the brick sample specimens. The details about the estimation of these three physicosintering properties were described elsewhere (Ghale 2018).

$$
\begin{aligned}
& \text { Water Absorption }(\%)=\frac{S-D}{D} \times 100 \\
& \text { Apparent Porosity }(\%)=\frac{S-D}{V} \times 100 \\
& \text { Bulk Density }\left(\mathrm{g} / \mathrm{cm}^{3}\right)=\frac{D}{V}
\end{aligned}
$$

The mechanical property of the compressive strength of the seven ancient clay brick samples was estimated in accordance with ASTM standards (ASTM C1424-15 2015) using the RAM DIA 222-2 mm with maximum load of $2000 \mathrm{KN}$ compression testing machine available at the Central Material Testing Laboratory, Department of Civil Engineering of Pulchowk Engineering Campus, Tribhuvan University, Lalitpur using equation (4) as given below. The details about the estimation of the compressive strength of the seven ancient brick samples were described elsewhere (Bohara et al. 2018).

Compressive Strength $\left(\mathrm{N} / \mathrm{mm}^{2}\right)=\frac{\text { Maximum load at failure }(\mathrm{N})}{\text { Average area of bed face }\left(\mathrm{mm}^{2}\right)}$ 


\section{RESULTS AND DISCUSSION}

The physico-sintering and mechanical properties of the clay brick samples depend on the optimum conditions maintained at the time of their manufacturing. Basic physico-sintering (i.e., water absorption capacity, bulk density and apparent porosity) and mechanical (i.e., flexural or compressive strength) properties act as the quality control and durability of the clay bricks, which ultimately depend on the phase and chemical compositions of their raw materials. Figure 2 shows the changes in the water absorption capacity of the archaeologically important seven ancient clay brick samples from historical places of Kathmandu valley. It is clearly shown from the figure that all the analyzed clay brick samples show the water absorption capacity in the range of 9.7-27.7 percent (Fig. 2). Only one brick sample of Clock Tower (i.e., DB-3) show the water absorption capacity less than 10 percent, while two brick samples of DB-2 and DB-5 show more than 25 percent of water absorption capacity as depicted in Fig. 2.

Fig. 2: Water absorption capacity of the archaeological clay brick samples

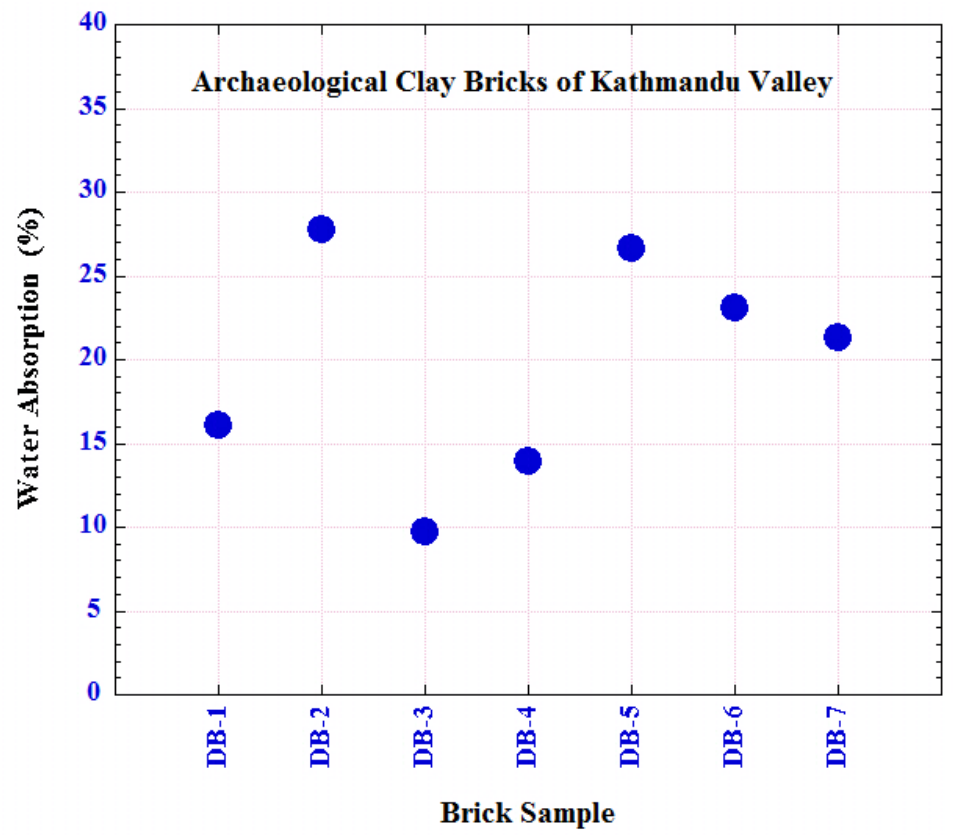


The water absorption capacity is one of the important criteria for representing the quality and strength of the clay bricks. A lower value of the water absorption capacity is always desired for good quality of clay bricks. The differences in the mineralogical phases of the raw materials of the ceramic body controls the water absorption capacity and the low water absorption value of the brick sample should be due to the presence of high amounts of clay minerals content in their composition with high densification, low porosity and high bulk density. Therefore, the apparent porosity (Fig. 3) of the brick samples used in this study is found to be decreased with decreasing the water absorption capacity (Fig. 2). It is clearly shown from the Fig. 3 that all the analyzed ancient clay brick samples show the apparent porosity in the range of 16.9-33.2 percent. Among these seven archaeologically important brick samples, DB-3 (i.e., Clock Tower) show the apparent porosity less than other six brick samples, while four brick samples of DB-2, DB-5, DB-6 and DB-7 show its values between 31.4 and 33.2 percent as shown in Fig. 3.

Similarly, the estimated result of the bulk density of all seven archaeological clay brick samples of Kathmandu valley is shown in Fig. 4. It is clear from the figure that brick samples of DB-1, DB-3 and DB-4 show the bulk density in the range of $1.53-1.75 \mathrm{~g} / \mathrm{cm}^{3}$, while remaining four brick samples show it between 1.2 and $1.5 \mathrm{~g} / \mathrm{cm}^{3}$ as shown in Fig. 4. It is generally considered that the clay brick samples having low water absorption capacity and apparent porosity have high bulk density and expected high mechanical strength also.

Furthermore, there is a good correlation between the water absorption capacity, apparent porosity and bulk density of all analyzed clay bricks. Both the water absorption and apparent porosity of the brick samples are found to be decreased with increasing the bulk density as depicted in Fig. 5. These results are mostly supported by the facts that the low density value observed for the brick samples is directly related to their high apparent porosity and high water absorption capacity with low particle packing in the brick bodies. In general, it is believed that the fired bricks have expected high bulk density and mechanical strength of compressive strength with low water absorption capacity and apparent porosity. 
8 STUDY ON THE PHYSICAL AND MECHANICAL PROPERTIES ...

Fig. 3: Apparent Porosity of the archaeological clay brick samples

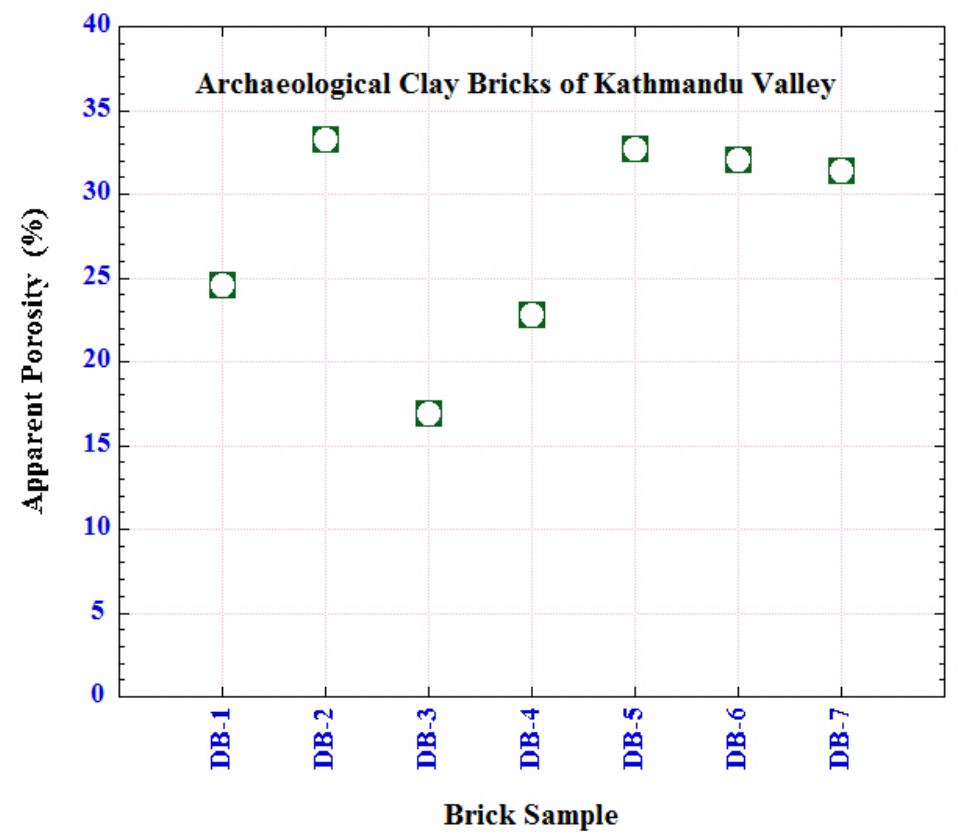

Fig. 4: Bulk density of the archaeological clay brick samples

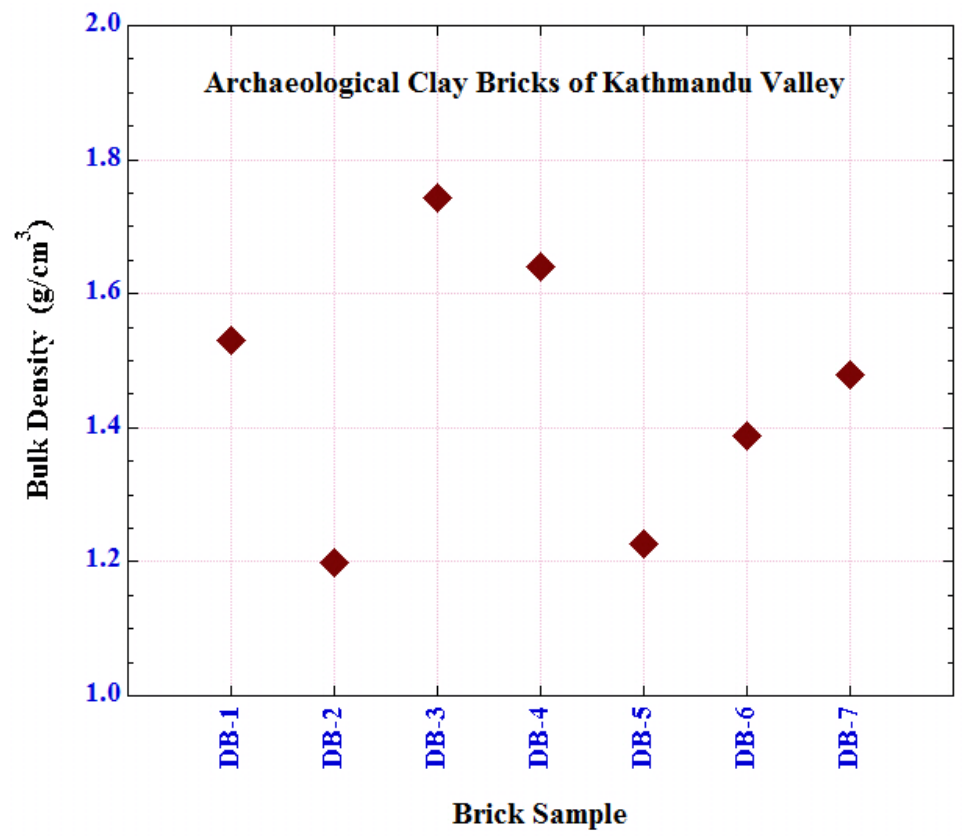


Fig. 5: Relation between the water absorption as well as apparent porosity with the bulk density of the archaeological clay brick samples

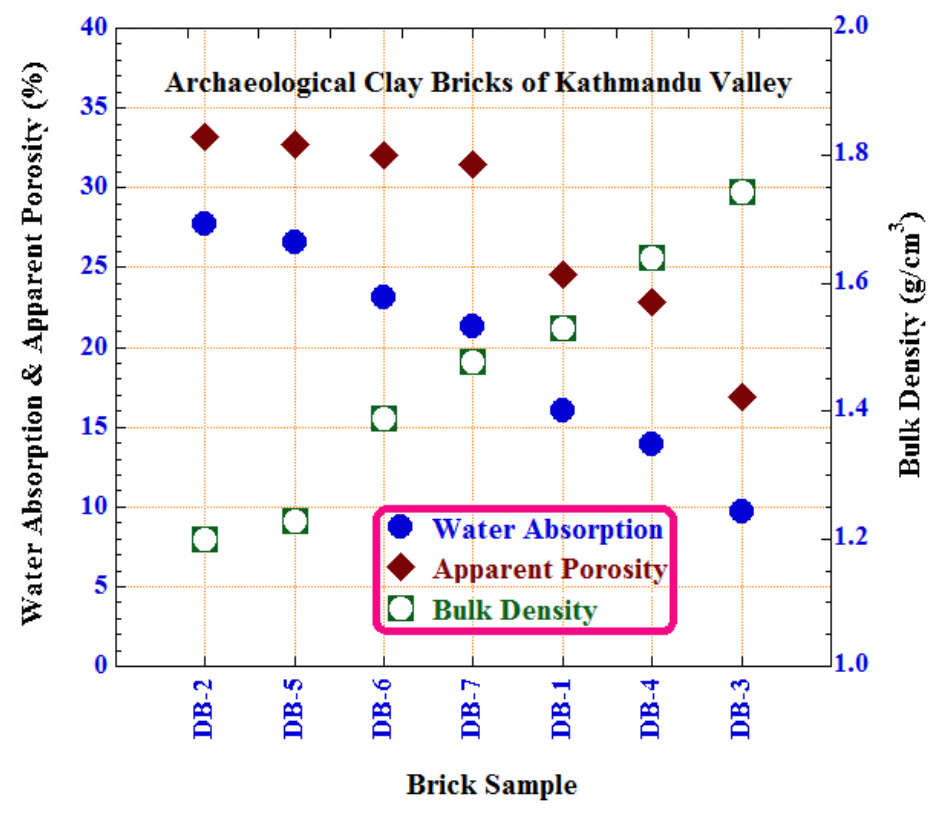

Different techniques are discussed for testing of various mechanical properties like compressive strength (ASTM C1424-15 2015), flexural strength (ASTM C1161-13 2013), static fracture toughness (ASTM C1421-16 2016) and so on. However, it is generally practice to estimate the compressive strength of brittle ceramic bodies like brick samples and hence this study was focused to measure the compressive strength of the archaeologically important seven brick samples collected from different historical sites of Kathmandu valley to correlate it with other physical properties as describe above. Figure 6 shows the result of the estimated compressive strength of the collected seven ancient brick samples from historically important places of Kathmandu valley. 
Fig. 6: Compressive strength of the archaeological clay brick samples

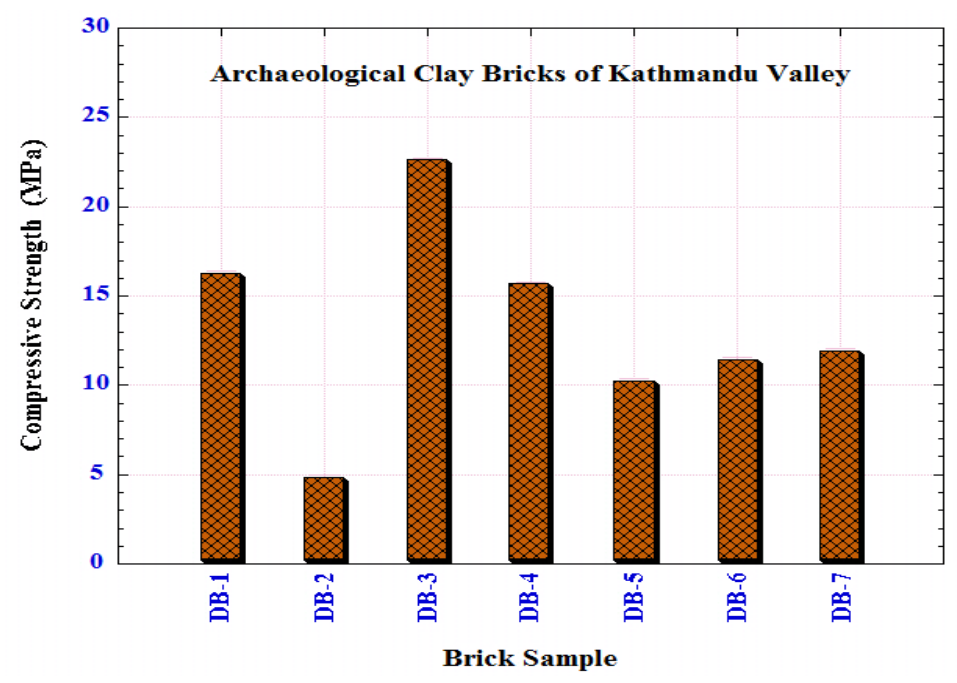

It is clear from the figure that one brick sample of DB-2 of Basantapur Darbar Square shows the lowest compressive strength of about $5 \mathrm{MPa}$ only among seven samples used in this study which is assumed to be low compressive strength value than that of the standard brick samples. Although, remaining other six brick samples have the compressive strength in the range of 10.4-22.7 MPa as shown in Fig. 6.

On the other hand, both the water absorption capacity and the apparent porosity of these bricks are deleterious to the mechanical properties of ceramic bodies like brick samples due to the following two reasons: firstly, the pores reduce the cross-sectional area across in which a load is applied and secondly, they also act as stress concentrators; for example, an applied tensile stress is amplified by a factor of 2 for an isolated spherical pore (Coble and Kingery 1956). It is generally considered that high mechanical strength of the ceramic bodies like clay bricks is also related with their physical properties like low water absorption capacity, low apparent porosity and high bulk density.

The influence of porosity on the mechanical properties of ceramic bodies is rather dramatic; for example, it is not uncommon that 10 percent volume porosity will decrease the flexural strength by 50 percent from the measured value for the nonporous materials. It was reported that the flexural strength decreased exponentially with volume fraction porosity 
experimentally (Callister 2010) and now we considered that such relations could be explained for compressive strength of the brick samples like flexural strength. There is a good correlation between the compressive strength with all these three types of physical properties (i.e., water absorption, apparent porosity and bulk density) of all the analyzed archaeologically important seven clay brick samples used in this study as shown in Figs 7-9. The compressive strength of the brick samples is found to be increased exponentially with decreasing the water absorbtivity and apparent porosity exponentially as shown in Fig. 7, although the compressive strength of the brick samples is increased with increasing their bulk density as shown in Fig. 8.

Fig. 7: The influence of the water absorption and apparent porosity on the compressive strength of the archaeologically important brick samples

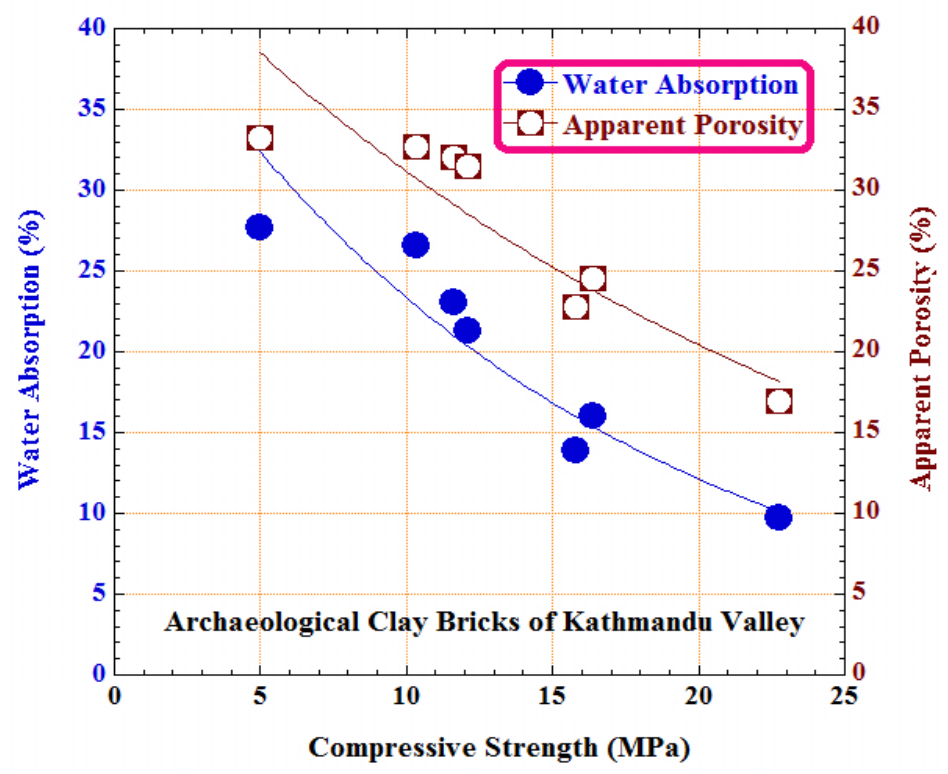


Fig. 8: Relation between the compressive strength and bulk density of the archaeologically important brick samples

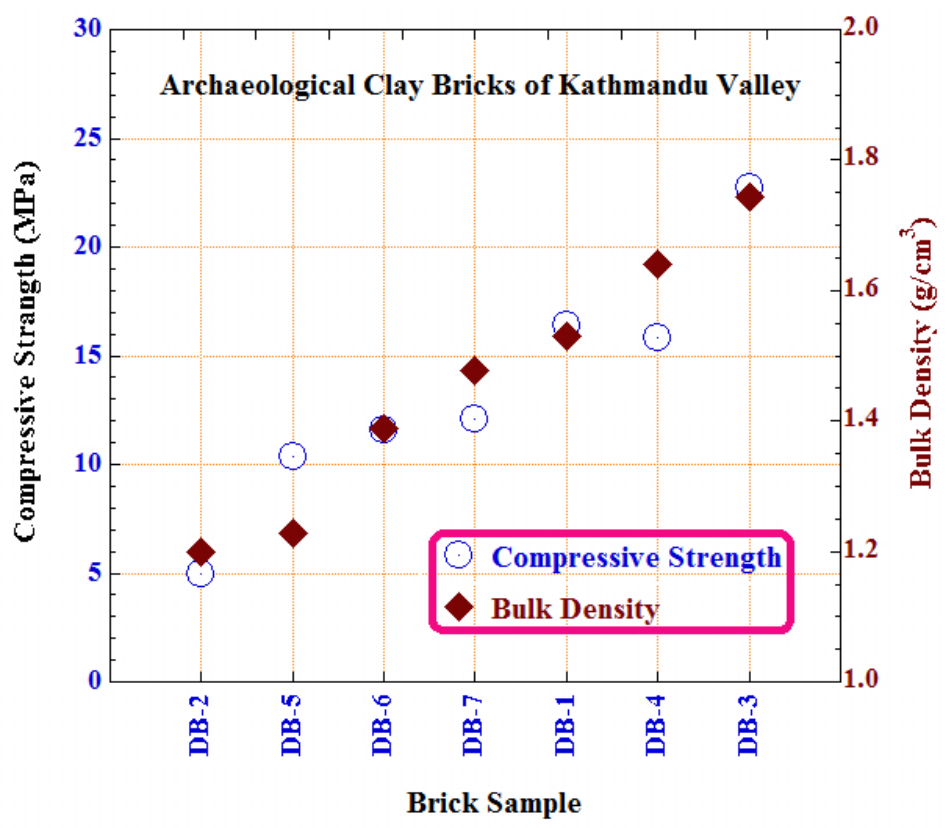

The compressive strength of the brick samples is directly related with the bulk density. Consequently, it can be said that efforts need to focus on decreasing both the water absorbtivity as well as the apparent porosity and on increasing the bulk density in order to improve the mechanical properties of the clay brick samples, because these physical properties of water absorbtivity, apparent porosity and bulk density are largely responsible for the betterment of all ceramic bodies like clay bricks. Moreover, a good correlation between compressive strength, water absorption, apparent porosity and bulk density of the brick samples is shown in Fig. 9 and the estimated values of these properties are tabulated in Table 2. 
Fig. 9: The influence of the water absorption, apparent porosity and bulk density on the compressive strength of the archaeologically important brick samples

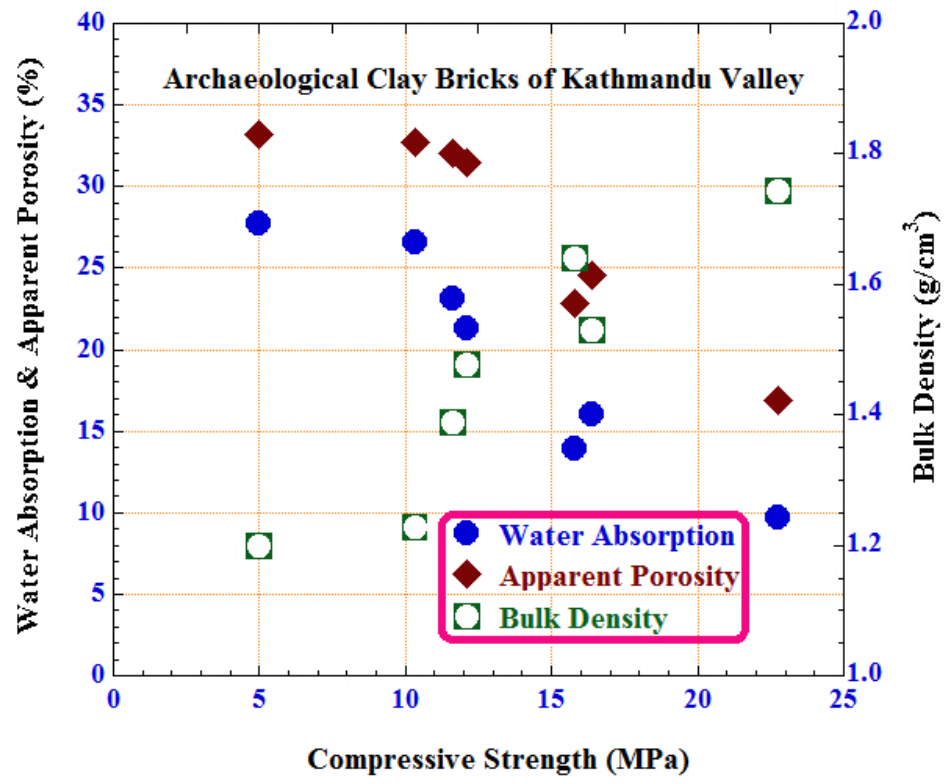

Table 2: Description of the archaeologically important clay brick samples used in this study

\begin{tabular}{|c|c|c|c|c|}
\hline $\begin{array}{c}\text { Sample } \\
\text { Name }\end{array}$ & $\begin{array}{c}\text { Water } \\
\text { Absorption } \\
(\%)\end{array}$ & $\begin{array}{c}\text { Apparent } \\
\text { Porosity } \\
(\%)\end{array}$ & $\begin{array}{c}\text { Bulk } \\
\text { Density (g/ } \\
\left.\mathrm{cm}^{3}\right)\end{array}$ & $\begin{array}{c}\text { Compressive } \\
\text { Strength } \\
(\mathrm{MPa})\end{array}$ \\
\hline DB-1 & 16.05 & 24.56 & 1.53 & 16.41 \\
\hline DB-2 & 27.72 & 33.23 & 1.20 & 5.00 \\
\hline DB-3 & 9.70 & 16.92 & 1.74 & 22.75 \\
\hline DB-4 & 13.90 & 22.80 & 1.64 & 15.80 \\
\hline DB-5 & 26.62 & 32.69 & 1.23 & 10.35 \\
\hline DB-6 & 23.10 & 32.07 & 1.39 & 11.59 \\
\hline DB-7 & 21.27 & 31.44 & 1.48 & 12.09 \\
\hline
\end{tabular}




\section{CONCLUSION}

The present research work was focused to study the physical and mechanical properties of seven archaeological clay bricks of Kathmandu valley for their quality assessments using ASTM standards and the following conclusions are drawn from above results and discussion.

It is found A good correlation between the physical properties of water absorption, apparent porosity and bulk density with the mechanical property of compressive strength was found for brick samples of seven historically important places of Kathmandu valley.

All the ancient clay brick samples used in this study have low water absorption as well as apparent porosity and high bulk density which are responsible for their high compressive strength and vice versa.

The water absorption, apparent porosity and bulk density are largely responsible for the betterment of the mechanical property of compressive strength of the brick samples used in this study and hence efforts need to focus on decreasing both the water absorption capacity and apparent porosity with increasing the bulk density in order to improve the mechanical properties of the bricks.

\section{ACKNOWLEDGEMENTS}

Authors would like to acknowledge University Grants CommissionNepal (UGC-Nepal) for providing the UGC Faculty Research Grant2072/073 to conduct this research work.

\section{REFERENCES}

Ajala, A.J., Badarulzaman, N.A. and Aramjat, A.B. (2017b). Influence of sintering temperatures on physico-mechanical properties and microstructure of refractory fireclay bricks. International Journal of Engineering and Technology 8(6): pp. 2588-2593. Retrived form https://doi.org/10.21817/ijet/2016/v8i6/160806214

Ajala, A.J.; Badarulzaman, N.A. and Aramjat, A.B. (2017a). Impact of sintering temperatures on microstructure, porosity and mechanical strength of refractory brick. Materials Science Forum 888: pp. 66-70. Retrived form https://doi.org/10.4028/www.scientific.net/ MSF.888.66

Amadori, M. L., Pallante, P., Fermo, P., Emami, M., Chaverdi, A. A., Callieri, P. And Matin, E. (2017). Advances in Achaemenid brick manufacturing technology: Evidence from the monumental gate at 
Tol-e Ajori (Fars, Iran). Applied Clay Science 152: pp. 131-142. Retrived form https://doi.org/10.1016/j.clay.2017.11.004

ASTM C1161-13 (2013). Standard test method for flexural strength of advanced ceramics at ambient temperature, In Annual Book of ASTM Standards, ASTM International, West Conshohocken, USA. Retrived form https://doi.org/10.1520C1161-13

ASTM C1421-16 (2016). Standard Test Methods for Determination of Fracture Toughness of Advanced Ceramics at Ambient Temperature, In Annual Book of ASTM Standards, ASTM International, West Conshohocken, USA. Retrived form https://doi.org/10.1520/ C1421-16

ASTMC1424-15(2015). Standard Test Methods for Monotonic Compressive Strength of Advanced Ceramics at Ambient Temperature. Annual Book of ASTM Standards, ASTM International, West Conshohocken, USA. Retrived form https://doi.org/10.1520/ C1424-15

ASTM C20-00 (2015). Standard Test Methods for Apparent Porosity, Water Absorption, Apparent Specific Gravity and Bulk Density of Burned Refractory Brick and Shapes by Boiling Water. Annual Book of ASTM Standards, ASTM International, West Conshohocken, USA. Retrived form https://doi.org/10.1520/C0020-00R15

Bartz, W. and Chorowska, M. (2016). Mineralogy and technology of bricks used for the construction of the XII century ducal castle on the island of Ostrów Tumski, Wrocław (SW Poland). Geoscience Records 2(1): pp. 4-16. Retrived form https://doi.org/10.1515/ georec-2016-0002

Bohara, N. B., Bhat, L. B., Ghale, D. B., Duwal, N. and Bhattarai, J. (2018). Investigation of the firing temperature effects on clay brick sample; part-I: mineralogical phase characterization. Bibechana 16: pp. 122-130 (2018). Retrived form https://doi.org/10.3126/bibechana. v16i0.21319

Bordia, R. K. and Camacho-Montes, H. (2012). Sintering: Fundamentals and Practice in Ceramics and Composites Processing Methods, Part-1: Densification. Pp. 3-42. In N. P. Bansal and A. R. Boccaccini((eds), $1^{\text {st }}$ edition, The American Ceramic Society, John Wiley and Sons, Inc.

Budhathoki, P., Duwal, N. and Bhattarai, J. (2018a). Investigation on physico-sintering and mechanical properties of clay tiles Available in Kathmandu valley of Nepal. Asian Journal of Chemistry 30(11): pp. 2515-2530. Retrived form https://doi.org/10.14233/ ajchem.2018.21509 
Budhathoki, P., Paudal, P., Oli, R.R., Duwal, N. and Bhattarai, J. (2018b). Assessment on the characterization of mineralogical phase of ceramic tiles available in Kathmandu valley (Nepal) using XRD and FTIR analyses. International Journal of Applied Science and Biotechnology 6(3): pp. 238-243. Retrived form https://doi. org/10.3126/ijasbt.v6i3.21171

Callister W. D., Jr. (2010). Materials Science and Engineering. John Willey and Sons, Hoboken, USA.

Cardiano, P., Ioppolo, S., Stefano, C., Pettignano, A., Sergi, S. and Piraino, P. (2004). Study and characterization of the ancient bricks of monastery of "San Filippo di Fragalà" in Frazzanó (Sicily). Analytica Chimica Acta 519(1): pp. 103-111. Retrived form https:// doi.org/10.1016/j.aca.2004.05.042

Coble R. L. and Kingery W. D. (1956). Effect of porosity on physical properties of sintered alumina. Journal of the American Ceramic Society 39: pp. 377-385. Retrived form https://dx.doi.org/10.1111/ j.1151-2916.1956.tb15608.x

Dondi, M., Marsigli, M. and Venturi, L. (1999). Microstructure and mechanical properties of clay bricks: comparison between fast firing and traditional firing. British Ceramics Transactions 98(1): pp. 1218. Retrived form https://doi.org/10.1179/096797899680183

Dunham, A. C., McKnight, A.S. and Warren, I. (2001). Mineral assemblages formed in Oxford clay fired under different time-temperature conditions with reference to brick manufacture. Proceedings of the Yorkshire Geological Society 53(3): pp. 221-230. Retrived form https://doi.org/10.1144/pygs.53.3.221

Elert, K., Cultrone, G., Navarro, C. R. and Pardo, E. S. (2003). Durability of bricks used in the conservation of historic buildings-influence of composition and microstructure. Journal of Cultural Heritage 4: pp. 91-99. Retrived form https://doi.org/10.1016/S12962074(03)00020-7

Fernandes, F. and Lourenço, P. B. (2007). Evaluation of the compressive strength of ancient clay bricks using microdrilling. Journal of Materials in Civil Engineering 19(9): pp. 791-800. Retrived form doi:10.1061/(ASCE)0899-1561(2007)19:9(791)

Fernandes, F. M., Lourenço, P. B. and Castro, F. (2010). Ancient Clay Bricks: Manufacture and Properties, Chapter-3. Pp. 29-48 in Dan M.B., Přikryl R., Török Á. (eds). Materials, Technologies and Practice in Historic Heritage Structures. Springer, Dordrecht. Retrived form https://doi.org/10.1007/978-90-481-2684-2_3 
Ghale, D. B. (2018). Investigation on the Moneralogy, Physical and Mechnical Properties of Ancient Bricks of Kathmandu Valley. M. Sc. Dissertation. Central Department of Chemistry, Tribhuvan University, Kathmandu, pp. 57+viii.

Ghale, D. B., Bohara, N. B., Duwal, N. And Bhattarai, J. (2018). Investigation on the mineralogical phase of ancient brick samples of Kathmandu valley (Nepal) using XRD and FTIR analysis. Rasaayan Journal of Chemistry (in press).

Ghorbel,A., Fourati, M. and Bouaziz, J.(2008). Microstructural evolution and phase transformation of different sintered kaolins powder compacts. Materials of Chemistry and Physics 112: pp. 876-885. Retrived form https://doi.org/10.1016/j.matchemphys.2008.06.047

Hasan, A. (1999). The Art and Science of Brick Making, $1^{\text {st }}$ edition. Pp. $1-10$.

Johari, I., Said, S., Hisam, B., Bakar, A. and Ahmad, Z.A. (2010). Effect of the change of firing temperature on microstructure and physical properties of clay bricks from Beruas (Malaysia). Science of Sintering 42(2): pp. 245-254 (2010). Retrived form https://doi. org/10.2298/SOS1002245J

Karaman, S., Ersahin, S. and Gunal, H. (2006). Firing temperature and firing time influence on mechanical, physical properties of clay bricks. Journal of Science and Industrial Research 65(2): pp. 153-159. Retrived form http://nopr.niscair.res.in/handle/123456789/4811

López-Arce, P., Garcia-Guinea, J., Gracia, M. and Obis, J. (2003). Bricks in historical buildings of Toledo city: characterization and restoration. Materials Characterization 50(1): pp. 59-68. Retrived form https:// doi.org/10.1016/S1044-5803(03)00101-3

Martin-Marquez, J., Rincon, J.M. and Romero, M. (2010). Effect of microstructure on mechanical properties of porcelain stoneware. Journal of the European Ceramic Society 30(15): pp. 3063-3069. Retrived form https://doi.org/10.1016/j.jeurceramsoc.2010.07.015

Mostaghelchi, M., Zahiri, R., Miremad, S. H. and Ebadi, A. G. (2013). Use of mica mineral powder in bricks industry to improve the performances. Asian Journal of Chemistry 25(16): pp. 9144-9148. Retrived form https://doi.org/10.14233/ajchem.2013.15053C

Njoya, D., Tadjuidje, F.S., Ndzana, E.J.A., Pountouonchi, A., TessierDoyen, N. And Lecomte-Nana, G. (2017). Effect of flux content and heating rate on the microstructure and technological properties of Mayouom (Western-Cameroon) kaolinite clay based ceramics. Journal of Asian Ceramic Societies 5(4): pp. 422-426. Retrived form https://doi.org/10.1016/j.jascer.2017.09.004 
Oguz, C., Turker, F. and Kocka, N. U. (2014). Construction materials used in the historical Roman Era bath in Myra. Scientific World Journal 2014, Article ID 536105, pp. 1-9. Retrived form http://dx.doi. org $/ 10.1155 / 2014 / 536105$

Paama, L., Pitkanen, I. and Peramaki, P. (2000). Analysis of archaeological samples and local clays using ICP-AES, TG-DTG and FTIR techniques. Talanta 51(2): Pp. 349-357. Retrived form https://doi. org/10.1016/S0039-9140(99)00281-7

Rasmussen, K. L., De La Fuente, G. A., Bond, A. D., Matheesen, K. K. and Vera, S. D. (2012). Pottery firing temperatures: a new method for determining the firing temperature of ceramics and burnt clay. Journal of Archaeological Science 39(6): pp. 1705-1716. Retrived form https://doi.org/10.1016/j.jas.2012.01.008

Šarić, K., Bikić, V. and Erić, S. (2018). Microstructural, mineralogical and petrographical characteristics of the medieval ceramics from the Studenica monastery (UNESCO world heritage site): Implications on the pottery technology and provenance of the raw material. Microscopy and Microanalysis 24(6): pp. 744-761. Retrived form https://dx.doi.org/10.1017/S1431927618015349

Shu, C.X., Cantisani, E., Fratini, F., Rasmussen, K.L., Rovero, L, Stipo, G. and Vettori S. (2017). China's brick history and conservation: laboratory results of Shanghai samples from $19^{\text {th }}$ to $20^{\text {th }}$ century. Construction and Building Materials 151: pp. 789-800. Retrived form http://dx.doi.org/10.1016/j.conbuildmat.2017.06.094

Vandiver, P. (2001). The role of materials research in ceramics and archaeology. Annual Review of Materials Research 31: pp. 373-385. Retrived form https://doi.org/10.1146/annurev.matsci.31.1.373

Velraj, G., Janaki, K., Musthafa,A.M. and Palanivel, R.(2009). Spectroscopic and porosimetry studies to estimate the firing temperature of some archaeological pottery shreds from India. Applied Clay Science 43(3-4): pp. 303-307. Retrived form https://doi.org/10.1016/j. clay.2008.09.005

Yongue-Fouateu, R., Ndimukong, F., Njoya, A., Kunyukubundo, F. And Mbih, P.K. (2016). The Ndop plain clayey materials (Bamenda area- NW Cameroon): Mineralogical, geochemical, physical characteristics and properties of their fired products. Journal of Asian Ceramic Societies 4(3): pp. 299-308. Retrived form https:// dx.doi.org/10.1016/j.jascer.2016.05.008 